
університету. - Серія "Регіональна економіка". - Випуск 16 (63). - Редкол.: відп. ред. д.е.н., професор Л.Л. Ковальська - Луиьк: ІВВ Луиького НТУ, 2019. -173 с.

УДК 332.341 .1

Ковальська Л.Л., д.е.н., проф., завідувач кафедри підприємництва, торгівлі та

біржової діяльності

Луцького національного технічного університету

\title{
РЕГІОНАЛЬНА ГОСПОДАРСЬКА СИСТЕМА: СУТНІСТЬ ТА СТРУКТУРИЗАЦІЯ
}

У статті проведено дослідження сутнісної характеристики поняття «господарська система». Виділено три підходу до змісту поняття «господарська система»: господарська система як інструмент планової економіки; господарська система як сукупність суб'єктів господарювання; господарська система як сукупність взаємопов'язаних елементів. Подано авторське бачення сутнісної характеристики регіональної господарської системи. Проведено структуризацію регіональної господарської системи.

Ключові слова: регіон, регіональна господарська система, суб'єкт господарювання, виробничі ресурси, ланцюг створення вартості, обслуговуюча підсистема.

\section{Kovalska L.}

\section{REGIONAL ECONOMIC SYSTEM: ESSENCE AND STRUCTURING}

The article deals with the study of the essential characteristics of the concept of "economic system". There are three approaches to the content of the concept of "economic system": economic system as a tool of planned economy; economic system as a set of economic entities; economic system as a set of interrelated elements. The author's vision of the essential characteristics of regional economic system under which proposed to understand the complex system composed of interrelated elements which function by interacting with environmental factors, aimed at ensuring the implementation of the various economic activities of the region is presented. The structuring of the regional economic system is carried out. It is indicated that the economic system can function at different levels of management: micro-level, meso-level and macro-level. The structuring of the regional economic system was carried out. It is proposed to include in the structure of the regional economic system such elements as the subject, the object of management of the regional economic system, the production resources of the region, the value chain (in circulation) and the service subsystem. It is noted that the subject of management of the regional economic system are territorial authorities; 
Економічні науки: збірник наукових праџь Луцького національного технічного університету. - Серія "Регіональна економіка". - Випуск 16 (63). - Редкол.: відп. ред. д.е.н., професор Л.Л. Ковальська - Луцьк : ІВВ Луцького НТУ, 2019. -173 с.

the objects of management of the regional economic system are economic entities, production resources that they dispose of (material, technical, financial, human, information), as well as the value chain (in circulation). It is proposed to consider financial and credit institutions, transport and insurance organizations, as well as regulatory and institutional support as servicing subsystems. It is proved that the essence of the structuring of the regional economic system is that all its constituent elements interact with each other providing a comprehensive approach to its consideration, which will allow obtaining a reliable, stable, operational and effective system of economy of the region as a whole.

Key words: region, regional economic system, business entity, production resources, value chain, service subsystem.

Ковальская Л.Л.

\section{РЕГИОНАЛЬНАЯ ХОЗЯЙСТВЕННАЯ СИСТЕМА: СУЩНОСТЬ И СТРУКТУРИЗАЦИЯ}

В статье проведено исследование сущностной характеристики понятия «хозяйственная система». Выделены три подхода к содержанию понятия «хозяйственная система»: хозяйственная система как инструмент плановой экономики; хозяйственная система как совокупность субъектов хозяйствования; хозяйственная система как совокупность взаимосвязанных элементов. Представлено авторское видение сущностной характеристики региональной хозяйственной системы. Проведено структурирование региональной хозяйственной системы.

Ключевые слова: регион, региональная хозяйственная система, субъект хозяйствования, производственные ресурсы, цепь создания стоимости, обслуживающая подсистема.

\section{Постановка проблеми у загальному вигляді та її зв'язок із важливими науковими чи практичними} завданнями. Формування постіндустріального типу економіки, якому притаманні процеси трансформації господарського комплексу регіону, інтенсивного розвитку міжнародного, національного та регіонального ринків, забезпечення розвитку економіки знань, характеризується появою нових трендів щодо управління усіма суспільними явищами та процесами. Результатом такого управління має стати забезпечення тісного взаємозв'язку між усіма елементами різного роду та рівня систем, що дозволить отримати синергетичний ефект від такої взаємодії та максимально ефективно підійти до здійснення усіх 
Економічні науки: збірник наукових праџь Луцького національного технічного університету. - Серія "Регіональна економіка". - Випуск 16 (63). - Редкол.: відп. ред. д.е.н., професор Л.Л. Ковальська - Луцьк: ІВВ Луцького НТУ, 2019. - 173 с.

господарських процесів в межах функціонування систем. У зв'язку із цим, актуалізуються питання щодо управління господарськими системами на різних рівнях, в т.ч. i регіонального.

Аналіз останніх досліджень і публікацій, в яких започатковано розв'язання даної проблеми. Дослідженням питань сутності та особливостей управління регіональними господарськими системами займались такі науковці як Вінник О. [4], Заргана М. [7], Кравець I. [5], Кожемякин С. [3], Лаптев В. [1], Пронська Г. [2] та інші. Проте, незважаючи на такі дослідження, і досі $є$ дискусійними питання сутності та структуризації регіональної господарської системи та інших питань щодо ії функціонування.

Цілі статті. Тому, метою дослідження стане 3'ясування економічної сутності змісту поняття «регіональна господарська система» та здійснення іiі структуризації.

Виклад основного матеріалу дослідження 3 повним обгрунтуванням отриманих наукових результатів. Проведемо огляд літератури змісту поняття «господарська система» (табл.1).

В рамках першого підходу науковці Лаптев В. [1], Пронська Г. [2] розглядали господарську систему як інструмент планової економіки. В основному, вони акцентували свою увагу на дослідженні діяльності суб'єктів господарювання, що функціонують відповідно до державного плану та $є$ елементом складного державного економічного механізму. Такий підхід був актуальним за часів командно-адміністративної системи управління, за якої спостерігалися встановлення та дотримання чітких планових галузевих показників діяльності усіх суб'єктів господарювання.

Другий підхід, представниками якого є Вінник О. [4], Кравець I. [5], Кожемякин С. [3], спрямований на розгляд господарської системи як сукупності суб' єктів господарювання. Зазначається, що суб'єкти господарювання повинні дотримуватись своїх прав та виконання обов'язків, а також ефективно розпоряджатися своїми ресурсами. В якості таких 
Економічні науки: збірник наукових праць Луцького національного технічного університету. - Серія "Регіональна економіка". - Випуск 16 (63). - Редкол.: відп. ред. д.е.н., професор Л.Л. Ковальська - Луиьк: ІВВ Луцького НТУ, 2019. - 173 с.

суб'єктів господарювання можуть бути підприємства, організації, установи різних форм власності, об'єднані територіальні громади, органи місцевого самоврядування тощо.

Таблиця 1

Огляд літератури змісту поняття «господарська система»

\begin{tabular}{|c|c|}
\hline Автор, джерело & Сутність поняття \\
\hline 1 & 2 \\
\hline \multicolumn{2}{|c|}{ Господарська система як інструмент планової економіки } \\
\hline Лаптев В. [1] & $\begin{array}{l}\text { «...єдиний виробничо-господарський комплекс, } \\
\text { що створений для планового здійснення } \\
\text { господарської діяльності та керівництва нею, що } \\
\text { складається } 3 \text { наділених господарською } \\
\text { компетенцією господарських органів, які } \\
\text { поєднані між собою стабільними зв'язками, один } \\
3 \text { яких є центром системи та володіє необхідним } \\
\text { для здійснення своєї діяльності майном і діє або } \\
\text { здатний діяти на основі госпрозрахунку» }\end{array}$ \\
\hline Пронская Г. [2] & 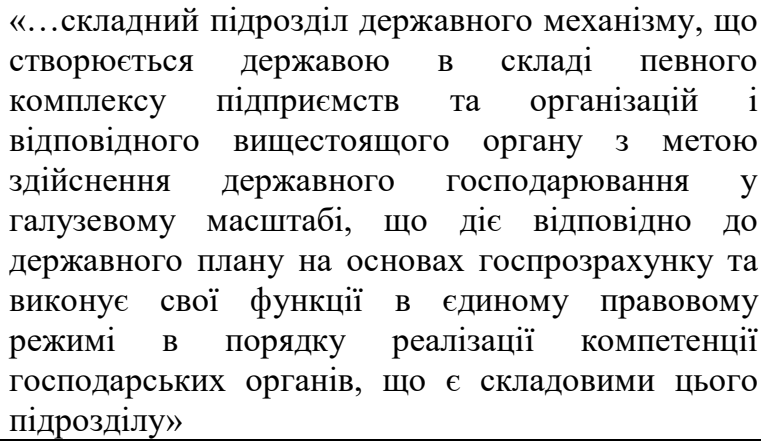 \\
\hline \multicolumn{2}{|c|}{ Господарська система як сукупність суб'єктів господарювання } \\
\hline Кожемякин С. [3] & $\begin{array}{l}\text { «...сукупність господарюючих } \\
\text { інтегрованих в одне ціле на підставі договоруів, або } \\
\text { статуту, або шляхом участі в капіталі або } \\
\text { управлінні» }\end{array}$ \\
\hline Вінник О. [4] & $\begin{array}{l}\text { «...такі системи взаємодіють із державою та } \\
\text { громадянським суспільством в особі суб’єктів } \\
\text { підприємництва як невід'ємних учасників таких } \\
\text { систем» }\end{array}$ \\
\hline
\end{tabular}


Економічні науки: збірник наукових прачь Луцького національного технічного університету. - Серія "Регіональна економіка". - Випуск 16 (63). - Редкол.: відп. ред. д.е.н., професор Л.Л. Ковальська - Луиьк: ІВВ Луиького НТУ, 2019. - 173 с.

\begin{tabular}{|c|c|}
\hline & Про \\
\hline 1 & 2 \\
\hline Кравець I. [5] & 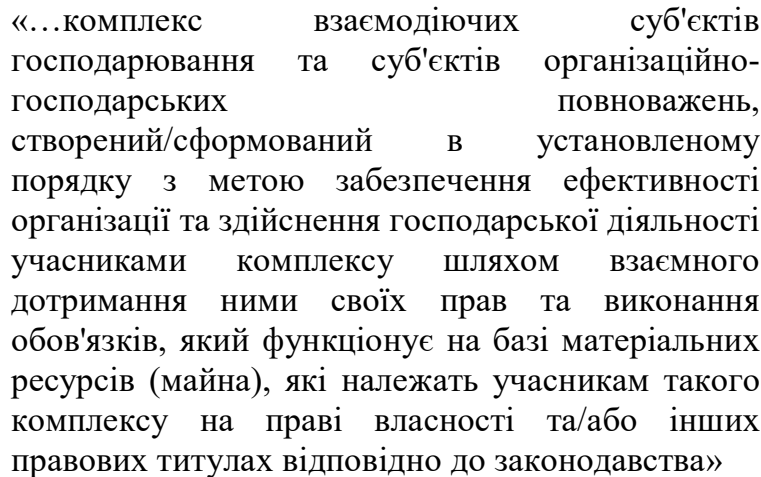 \\
\hline $\begin{array}{l}\text { Енциклопедія } \\
\text { сучасної України } \\
{[6]}\end{array}$ & $\begin{array}{l}\text { «...відносно відокремлений комплекс (група) } \\
\text { економічно та юридично пов'язаних між собою } \\
\text { суб’єктів господарської діяльності» }\end{array}$ \\
\hline \multicolumn{2}{|c|}{ Господарська система як сукупність взаємопов 'язаних елементів } \\
\hline Заргана М. [7] & $\begin{array}{l}\text { «...складна система, що складається із сукупності } \\
\text { елементів, між якими існують певні зв'язки, які } \\
\text { взаємодіють із зовнішнім та внутрішнім } \\
\text { економічним середовищем } 3 \text { допомогою певних } \\
\text { факторів і, створюють у процесі відтворення, } \\
\text { який охоплює як виробничі сили суспільства, так } \\
\text { i виробничі відносини людей, - матеріальні } \\
\text { блага» }\end{array}$ \\
\hline
\end{tabular}

Особливості третього підходу до розгляду господарської системи полягають у тому, що іiі розглядають (Заргана М. [7]) як сукупність взаємопов'язаних елементів. Вважаємо, що даний підхід є найбільш вдалим, оскільки дозволяє охопити не лише суб'єктів господарювання, але й інші елементи такої системи. В якості таких елементів можуть бути такі продуктивні сили як виробничі ресурси, що використовуються та трансформуються в межах господарської системи, ланцюг створення вартості (стадії обігу), обслуговуючі підсистеми (страхування, транспортування, кредитування, фінансування, інформування, нормативно-правове забезпечення тощо), і т.д. 
Економічні науки: збірник наукових прачь Луцького національного технічного університету. - Серія "Регіональна економіка". - Випуск 16 (63). - Редкол.: відп. ред. д.е.н., професор Л.Л. Ковальська - Луцьк: ІВВ Луиького НТУ, 2019. - 173 с.

Слід зауважити, що господарська система може функціонувати на різних рівнях управління: мікро-, мезо- та макрорівень. Мікрогосподарська система функціонує в межах окремих підприємств, організацій та установи, метою діяльності яких є отримання економічного результату. Мезогосподарські системи формуються для потреб функціонування відповідної інфраструктури економіки регіону [8, 9]. Макрогосподарська система - найбільша система управління, що охоплює суб'єктів господарювання та інші iї елементи, які розміщені в різних регіонах держави, чи поза іiі межами. В цілому, така господарська система інтегрує в собі інфраструктуру економіки держави чи групи країн.

Оскільки, об'єктом дослідження є регіональна господарська система, то будемо іiі розглядати як складну систему, що складається із сукупності взаємопов'язаних елементів, функціонування яких взаємодіючи із чинниками зовнішнього середовища, спрямоване на забезпечення здійснення різних видів господарської діяльності регіону.

Задля впорядкування та розмежування усіх господарських процесів та явищ, що відбуваються у межах регіональної господарської системи доцільною є іï структуризація (рис. 1). Отже, структура регіональної господарської системи складається із суб'єкта, об'єкта управління регіональною господарською системою, виробничих ресурсів регіону, ланцюга створення вартості (стадій обігу) та обслуговуючих підсистем.

Суб'єктом управління регіональною господарською системою є територіальні органи влади. Об'єктами управління регіональною господарською системою $є$ самі суб'єкти господарювання, суб'єкти організаційно-господарських повноважень, один 3 яких є центром господарської системи, а інші відповідно підпорядкованими центру учасниками господарської системи [5], виробничі ресурси, якими вони розпоряджаються (матеріально-технічні, фінансові, людські, інформаційні тощо), а також ланцюг створення вартості (стадії обігу). 
Економічні науки: збірник наукових прачь Луцького національного технічного університету. - Серія "Регіональна економіка". - Випуск 16 (63). - Редкол.: відп. ред. д.е.н., професор Л.Л. Ковальська - Луиьк: ІВВ Луиького НТУ, 2019. - 173 с.

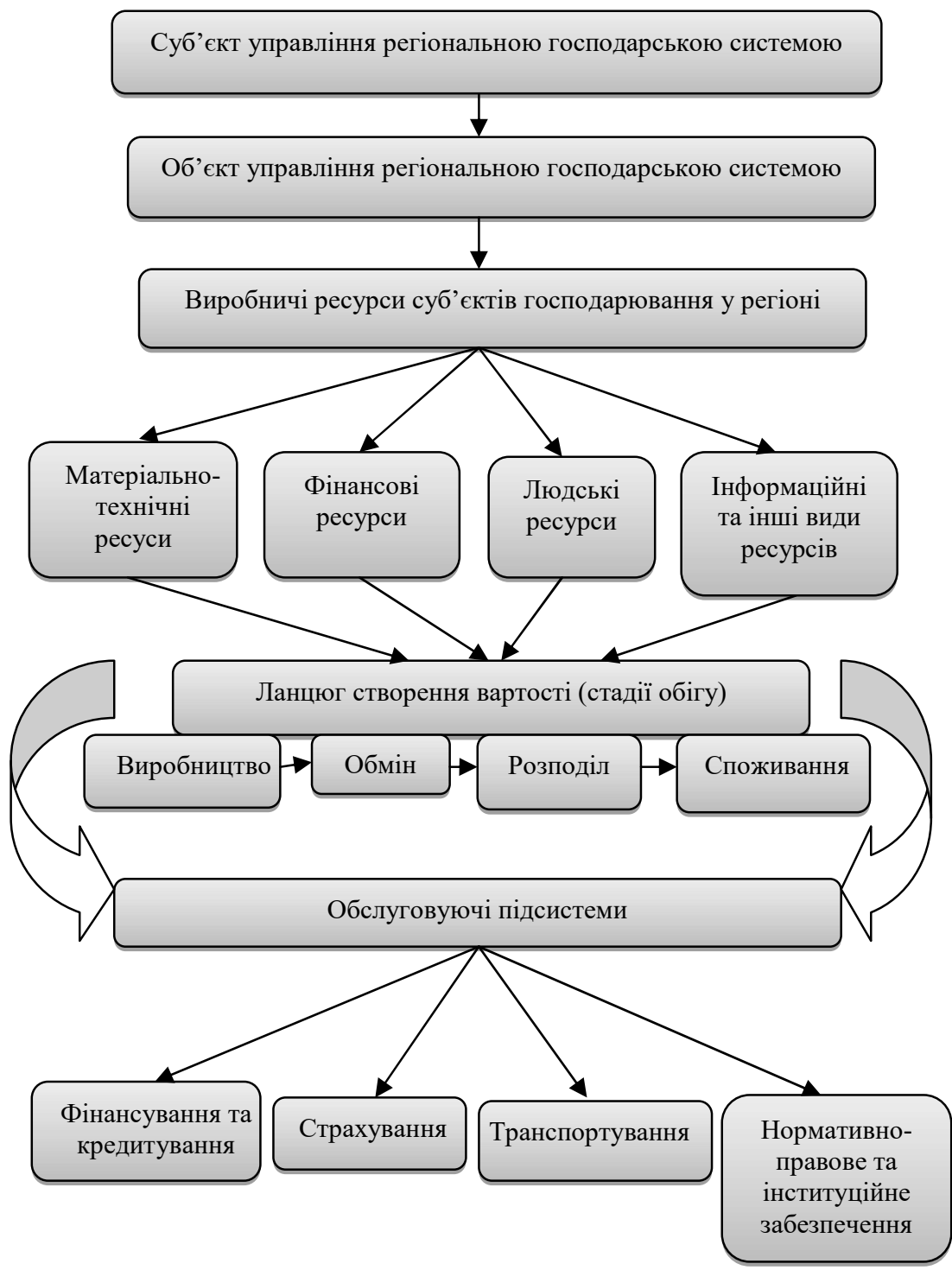

Рис.1. Структура регіональної господарської системи 
Економічні науки: збірник наукових праџь Луцького національного технічного університету. - Серія "Регіональна економіка". - Випуск 16 (63). - Редкол.: відп. ред. д.е.н., професор Л.Л. Ковальська - Луиьк: ІВВ Луиького НТУ, 2019. -173 с.

У межах регіональної господарської системи формується ланцюг створення вартості, або протікають такі процеси обігу як виробництво, обмін, розподіл та споживання, здійснення яких спрямоване, з однієї сторони на функціонування різних видів економічної діяльності, а з іншої - на максимальне задоволення потреб споживачів.

В якості обслуговуючих підсистем можуть бути фінансово-кредитні установи, транспортні та страхові організації, а також нормативно-правове та інституційне забезпечення, які надають послуги різного функціонального спрямування для здійснення ефективної господарської діяльності та отримання на цій основі позитивного фінансового результату.

Висновки. Отож, сутність структуризації регіональної господарської системи полягає у тому, щоб усі іiі складові елементи взаємодіяли між собою забезпечуючи комплексний підхід до іiі розгляду, що дозволить отримати надійну, стабільну, оперативну та ефективну систему господарства регіону в цілому.

1. Лаптев В.В. Правовая организация хозяйственных сис-тем. М. : Юридическая литература, 1978168 с. 3. Правовое положение промышленных и производственных объединений. М. : Наука, 1978. 247 с.

2. Пронская Г.В. Правовая организация отраслевых хозяйственных систем (на примере Украинской ССР). К. : Издательское объединение "Вища школа". 1985. 129 с.

3. Кожемякин С.А. Формирование права хозяйственных систем как подотрасли хозяйственного права Украины. Хозяйственное законодательство Украины : практика применения и перспективы развития в контексте европейского выбора : Сб. научных трудов [ред. В.К. Мамутов]. Донецк : ООО "Юго-Восток, Лтд", 2005. С. 189-193.

4. Вінник О., Кравець I. Господарські системи в умовах громадянського суспільства і правової держави: правові аспекти взаємодії. Господарське право і процес. №11. 2016. С. 62-67.

5. Кравець І. Поняття та класифікація сучасних господарських систем. вісник Київського національного університету імені Тараса Шевченка. Юридичні науки. 3(97)/2013. С. 71-76. 
Економічні науки: збірник наукових пращь Луцького національного технічного університету. - Серія "Регіональна економіка". - Випуск 16 (63). - Редкол.: відп. ред. д.е.н., професор Л.Л. Ковальська - Луиьк: ІВВ Луцького НТУ, 2019. - 173 с.

6. Енциклопедія сучасної України. http://esu.com.ua/search articles.php?id=31582.

7. Заргана М.А. Андреева В.Г. К вопросу о проблемах перспективного развития производственно-хозяйственных систем в Украине. Економічний простір. 2008. № 19. С. 50-56.

8. Крикавський Є.В., Чорнописька Н.В. Логістичні системи: Навч. посібнЛьвів: В-во НУ «Львівська політехніка», 2009. 264 с.

9. Ковальська Л.Л., Оксенюк К.І. Логістичний менеджмент. Навчальний посібник для студентів вищих навчальних закладів. 2016. Луцьк: РВВ ЛНТУ. 380 с. 